\title{
Innovation and Present Situation of Entrepreneurship Education in Colleges and Universities
}

\author{
Xiao Liu \\ Xijing University, shaanxi 710123 China \\ 75700789@qq.com
}

Keywords: New normal; Colleges and universities; Innovation and entrepreneurship; Mode; Innovation

\begin{abstract}
Under the new normal of economic, the major colleges and universities actively promote innovation and employment education, entrepreneurship model to drive employment. Changing the traditional way of education, training of social application of talent, are the powerful driving force of social development and the national prosperity. But universities in innovation and entrepreneurship education still existing many problems, this paper analyzes the status of innovation and entrepreneurship education, explores the pattern innovation of colleges and universities according to their own situation and how to stimulate the potential of entrepreneurship students, establish a multi-level system of entrepreneurship education.

In order to implement the Scientific Outlook on Development, construct the innovative national service, universities have carried out innovation and entrepreneurship education, to deepen the reform of education in Colleges and universities, improve the practical ability of students. Some colleges and universities have set up the corresponding innovation and entrepreneurship courses, which is also an important measure to adapt to the development of quality education reform. Under the new situation, innovation and entrepreneurship education can cultivate talents, serve the society and scientific research, change the transmission mode of the traditional knowledge, and stride forward to the ability and quality training.
\end{abstract}

\section{The Importance of Innovation and Entrepreneurship Education in Colleges and Universities under the New Normal Conditions}

To Meet the Requirements of the Construction of Innovative Country. As the main position of training talents, colleges and universities need to establish innovative consciousness and improve the ability of innovation to meet the requirements of building a new country. Therefore, universities should change the traditional education mode of imparting knowledge, build an efficient platform for college students to create innovative entrepreneurship education, establish a sound innovation and entrepreneurship system to cultivate students into innovative talents with both professional knowledge and entrepreneurial ability, and provide support for the country's independent innovation strategy.

Requirements for Transition of Application Oriented Undergraduate Colleges. This year, under the impetus of the reform of the Ministry of education, a lot of colleges and universities began to actively explore innovative development path, and gradually develop the application of college to achieve the University of Applied Science and technology. One of the important measures is to strengthen the innovation and entrepreneurship education for college students, as a breakthrough in the transition, is also the development of school characteristics, innovative talents training mode important way.

The Objective Requirement of College Students' Self-promotion. With the development of economic and social progress, the demand for talent getting higher and higher, a lot of college students after graduation in employment difficult situation, even to find a job, wages and salaries are not high which requires students to improve their ability of innovation, pioneering and entrepreneurial thinking. In school, students not only learn the corresponding professional theoretical knowledge, but also from the practice of teaching process, improve their practice, practical training ability, and improve their own independence of innovative ways of thinking to 
solve the problem. School education as a key period of cultivating students' innovative and entrepreneurial ability, should help students to establish a sense of innovation, to penetrate the professional knowledge learning and skills training into the concept of innovation and Entrepreneurship to improve the level of practice and help students to change the employment of thinking which not only can be a job but also can be the Creator.

\section{The Current Situation of College Students' Innovation and Entrepreneurship Education}

Colleges and Universities to Pay Attention to the Degree of Innovation Is Not Enough. Although the country vigorously advocate the innovation and entrepreneurship education in Colleges and universities, because of the new education courses in the practice of the operation of the University, it is difficult to quickly and the professional education of the University. Some colleges and universities have not changed personnel training programs; an innovation and entrepreneurship education course not included, but was marginalized. Only when university graduates are near the time to find a job before, do the colleges and universities carry on the innovation and entrepreneurship education, in the form of elective courses to cultivate students' innovation and entrepreneurship awareness. The influence of traditional education ideas, teachers still focus on the completion of teaching tasks, in the teaching process, do not attach importance to the cultivation of students' creative thinking and practical ability which is lack of educational motivation.

Lack Comprehensive Innovation and Entrepreneurship Education System. Because the competition of colleges and universities is gradually fierce, a lot of colleges and universities in order to expand the scale with a short of fund get impacted by importance degree on innovation and Entrepreneurship Education. Because investment limited, the corresponding teachers is limited and a lot of innovation and entrepreneurship teachers is halfway decent, with professional not strong causing the inevitable lack of entrepreneurship and innovation of teaching experience. Because of the relatively short development time of innovation and entrepreneurship education, the level of the corresponding personnel training system is poor and the facilities are not perfect. Students from fresh man year to senior, Ideas are changing gradually, but there is little change in the mode and content of the innovation and entrepreneurship education. It's generally theoretical teaching, not with the depth of professional courses, so that entrepreneurial knowledge can't keep up with the progress of professional knowledge. In addition, the corresponding curriculum system of innovation and entrepreneurship is not complete teaching objectives, tasks, outlines, and then in the form of elective, lectures, reports, etc..

Innovation and Entrepreneurship Education of University Students is out of Touch with Practice. As mentioned above, colleges and universities while opening the innovation and entrepreneurship education related courses, teachers are the shackles of the traditional idea of education, so education is mainly on the theory of curriculum knowledge as the main. This cramming method of teaching deprived students' initiative which is not conducive to the cultivation of the creative thinking of students. Teachers and students lack of communication and exchange. In addition, based on the theory of teaching, it is difficult for students to combine with internship and practice in the class, which will inevitably lead to a gap between the two. Many teachers have limited experience in teaching innovation and entrepreneurship education, with no original opinion for many cases of innovation and entrepreneurship, and can't effectively help students analyze. The cultivation of this empty talk teaching mode is not conducive to the talent.

No Sound the Innovation and Entrepreneurship Education Practice Platform. Colleges and universities establish a sound innovation and entrepreneurship education practice platform to provide students with the opportunity to combine theory and Practice. And at present, many colleges and universities are limited by the degree of attention and funding with no corresponding platform, and the lack of teachers and related equipment is also not conducive to the construction of the platform. Some colleges and universities have related training and entrepreneurship projects, also organize students to participate in the business competition, but often the results are not satisfactory. In order to do the project and do the project, there is business incubator Park, and other 
platforms in colleges and universities, but many of them are a mere formality. How to play the actual roles is a big problem, which leads to the innovation and entrepreneurship education of college students is not good.

\section{Construction of Innovation and Entrepreneurship Education Model in Colleges and Universities}

Establish a Sound Curriculum System to Help Students Establish the Concept of Innovation and Entrepreneurship. The most important to carry out innovation and entrepreneurship education in Colleges and universities is to improve the relevant curriculum system, because the curriculum is the carrier of Education. Firstly, colleges and universities can establish the relevant innovation and entrepreneurship curriculum system according to the specific situation, make full use of the developed network, absorb foreign excellent curriculum education experience, and introduce of advanced curriculum education system, according to the professional characteristics of the students in our school and the employment situation of the society to construct the characteristic education model.

Improve the Quality of Teachers, and Enhance the Practice of Innovation and Entrepreneurship Teaching. Construction of teacher's team directly affecting the innovation education and enterprise education plan, as a key part of higher education should establish complex, multi-level professional teachers, and unifies the school teacher training and the introduction of outstanding teachers. First of all, we can encourage professional teachers of the innovation and entrepreneurship courses in the school to enterprise internships to learn enterprise cooperation research projects which improve their own at the same time but also open up the path for students. Only the teachers accumulated practical experience, can distinguish between primary and secondary in the course of teaching, to explain in depth, to inspire students to start thinking. Secondly, colleges and universities can regularly organize teachers to participate in innovation and entrepreneurship education and training, for example, qualification training and certification, so as to further improve the professional level of Teachers. Colleges and universities can hire outstanding entrepreneurs or entrepreneurs and also the success of the school's graduates for college students, through the opening of lectures, seminars, etc. to allow students to close contact with them, to learn from their practical experience, so as to guide the cultivation of students' innovative thinking from the direction of the practitioner.

Colleges and Universities Establish a Platform of Innovation and Entrepreneurship, to Create Innovative Atmosphere for Students. First, colleges and universities, combined with their advantage resource to create a business incubator platform, at the same time, while strengthening the construction of College Students' science and Technology Park, should pay attention to the use of this platform, to guide students to play the creativity thinking, with the help and support a full range of policies, procedures, laws, etc., through the nursery - Incubator - accelerator and other layers of progressive way to encourage students to put forward the idea of entrepreneurship.

Second, to strengthen the links between universities and enterprises and make the university into a business training base, so college students in the school will be able to get practical training, to achieve zero distance employment. Colleges and universities can also co found the company with enterprises, and establish the R \& D base, through the open mode of cooperation, so that students can really get exercise, for example, colleges and universities and enterprise cooperation to obtain the training qualification certificate, so the vocational training certificate brought into the mode of innovation and Entrepreneurship Education.

Third, universities can establish venture fund for the achievement of innovation and Entrepreneurship Program Award, so on the one hand, it's convenient for students to apply innovative entrepreneurial projects, on the other hand, but also can provide financial support for students innovation projects, encouraging students to use the professional advantage enterprises to participate in the study and grasp the new technology and new methods. Students can choose take part in research projects, or engaging in related experiments according to their own interest and 
professional, through the teacher's guidance, technical innovation, which can combine teaching with research, to have the prospect of the project can be carried out to focus on support.

Strengthen the Guidance and Service for College Students' Innovation and Entrepreneurship. First, colleges and universities can establish the corresponding innovation and entrepreneurship management mechanism and evaluation system. Colleges and universities establish innovation and entrepreneurship guidance center, to make sure the relevant policies, clear the allocation of funds for the project, the responsibilities of personnel and related incentives. Through the establishment of guidance center, incubator platform and research office to improve the innovation and entrepreneurship education model system.

Second, colleges and universities is the base for training talents, to help students establish the concept of entrepreneurship to promote employment. Starting from the freshman, give them four years of career planning, from the beginning to establish a clear goal. Freshman establishing a sense of professional identity, sophomore determining the direction of employment, Junior improving the ability to adapt to the occupation, ready to switch roles, senior students need to combine their own advantages, improve the ability of innovation and job search.

Third, colleges and universities should do a good job in the follow-up work of innovation and Entrepreneurship Education. The new preferential policies for the introduction of College students, colleges and universities should be in a timely manner through a variety of ways to promote college students, publicity, to avoid the students blindly career choice. Colleges and universities using the innovative service platform, constantly updating information, collecting business news and the latest project, the scene simulation, evaluate students' entrepreneurial situation, provide information services to students at the same time and improve the success rate of entrepreneurship.

\section{Conclusion}

Although many colleges and universities have begun to explore the mode of innovation and entrepreneurship education, because it is in the primary stage, there is a great challenge. in the economy under the new normal, colleges and universities should combined with their own specific circumstances, planning innovation course system, to explore the relevant educational strategies and build more power to serve platform, stimulate students' positive entrepreneurial potential, cultivating innovative thinking and improve the success rate of entrepreneurship.

\section{References}

[1] $\mathrm{Du} \mathrm{Yu}$ bo, grasp the new normal development of higher education [N]. Guang ming Daily, 2015-03-02 (2)

[2] The state council, the opinion of the State Council office on deepening the implementation of innovation and entrepreneurship education in Colleges and universities EB/OL.Xinhuanet.com http: / /news.xinhuanet.com / politics / /2015-05 /13 C 1115272337.htm 2015-05-13. _.

[3] Lei Jia su, analyze on Domestic and foreign innovation and entrepreneurship education development (J). China Youth Science and technology, 2007 (2): 26-29.

[4] Zhao Jun, research on the function construction of College Students' innovation and entrepreneurship education information platform $[\mathrm{J}]$ Contemporary educational practice and teaching research, 2015 (09): 147-149.

[5] Xu Detao, research on the innovation and entrepreneurship education of college students [D]. Shandong University, 2013:33-36.

[6] Yin $\mathrm{Xi}$, research on the path of cultivating innovative talents in Colleges and universities [J].Journal of Linyi University, 2015, (02): 44-46.

[7] Hu tao, Shen Li, the enlightenment of foreign innovation and entrepreneurship education model to China's universities and colleges, 2013 (02): 91-94 
[8] Wang Jing, innovation and entrepreneurship education reform and development path of local application oriented universities [J]. management and management, 2015 (06): 146-149 